\title{
MODELING OF MATERIAL FLOWS OF MANUFACTURING FACILITY
}

\section{Solodovnik Ganna ${ }^{1}$ \\ Kovalenko Katerina ${ }^{2}$}

DOI: https://doi.org/10.30525/978-9934-571-89-3_120

Manufacturing facility of any sector and any form of ownership is a complex socio-economic system, that quickly changes performance indicator. The actuality is based on modeling of dynamics of material, financial and other flows of such systems by means of using modern ways of automatization. Most often a change of indicators

\footnotetext{
${ }^{1}$ Kharkiv National University of Civil Engineering and Architecture, Ukraine

${ }^{2}$ Kharkiv National University of Civil Engineering and Architecture, Ukraine 
of flows is described by differential and integral equations, but while automatization of reliances of such kind some difficulties appear. Using system dynamics of the method provides for transformation of such equations into linear dependences, considering a change of indicators within quite a small amount of time.

The aim of work is the modeling of material flows in the manufacturing facility with the use of methods of system dynamics.

An object of study is a facility - producer of SIP panels. A focus of the work is material flows of a manufacturing facility.

System dynamics- is modeling and imitation of complex socio-economic systems, that are characterized by generally far-reaching non-linear structures - control loops. The introduced methodology is aimed at computer modeling and is a powerful tool for investigating dynamic processes $[1 ; 2 ; 3$, p. 98-101].

The building of a computer model of material flows will be viewed in the facility of SIP panels- construction material, that has a three-layer structure, consisting of two leaves of hard material and one layer of instant between them.

Baseline data of model is an amount of unit value in the warehouse, the optimum volume of order and an amount of material of each type in the enterprise warehouse.

The building of a mathematical model is based on the following hypothesis: enterprise produces only one type of goods, enterprise works only with large-scale buyers, the enterprise has only one conveyor line.

The main baseline data of a model is a number of goods in the warehouse of an enterprise, that is determined using the following formula:

$$
S(t)=S(t-\tau)+\tau\left(\rho(t)-o^{l s b}(t)\right),
$$

where $\rho(t)$ - the pace of goods delivery to a warehouse;

$o^{l s b}(t)$ - the pace of goods delivery to large-scale buyers;

$S(t-\tau)$ - an amount of goods in a warehouse in a previous period of time;

$\tau$ - time interval between solutions of the equations.

The interval between solutions of the equations should be chosen based on the intensity of production. Moreover, this time interval is determined by delays, occurring in a process of enterprise functioning. Delays characterize a process of transformation, whereby on the basis of the pace of incoming flow the pace of flow, in the end, is established. In dynamic systems paces are variable amounts, therefore the pace of flow based on a certain level may not coincide with the pace of incoming flow at different times [3, p. 110].

Delays can occur at different stages of enterprise functioning. For instance, delays connected with the production process: from delivery of materials to an enterprise and dispatching finished goods to a warehouse, there can be a time interval that is equal to a production cycle. Delays of the first-order consist of a level (including the difference between flow paces- incoming and out coming) and a pace of an outgoing flow, based on level and an average duration of delays (intercept), a pace of incoming flow is determined by other model dependences. Delays of higher order are received with the help of inducting the flow through two or more consequent delays of the first 
order. Practically delays of the third order are used, that is a balancing act between complexity and accuracy while building a model.

The pace of goods dispatch to large-scale buyers depends on $Z^{l s b}(t)$ - a number of goods, ordered by large-scale buyers and is determined by the formula:

$$
o^{\text {опт }}(t)=\frac{Z^{l s b}(t)}{\tau} \text {. }
$$

According to assumptions, based on which the model was built, an enterprise vends goods only to large-scale buyers (it is specifically to producers of construction materials), herewith to this model a chain of retail trade can be added, with allowances made for determined value of an average demand on a definite type of goods.

The pace of goods delivery to a warehouse (pace of production $\rho(t)$ ) is determined by the lowest value among paces value: the pace of production, supplied with materials $\rho^{\text {mat }}(t)$ and planned production $\mathrm{p}$, needed for the fulfillment of orders of large-scale buyers $\rho^{\text {plan }}(t)$. Moreover, we should take into consideration a delay, connected with production, that is determined by a system of linear equations of the following type:

$$
\left\{\begin{array}{c}
\Lambda_{1}(t)=\Lambda_{1}(t-\tau)+\tau\left(\rho_{\text {in }}(t)-\rho_{1}(t)\right) ; \\
\rho_{1}(t)=\frac{\Lambda_{1}(t)}{1 / \xi^{\text {prod }}} ; \\
\Lambda_{2}(t)=\Lambda_{2}(t-\tau)+\tau\left(\rho_{1}(t)-\rho_{2}(t)\right) ; \\
\rho_{2}(t)=\frac{\Lambda_{2}(t)}{1 / 3 \xi^{\text {prod }}} ; \\
\Lambda_{3}(t)=\Lambda_{3}(t-\tau)+\tau\left(\rho_{2}(t)-\rho(t)\right) ; \\
\rho(t)=\frac{\Lambda_{3}(t)}{1 / 3 \xi^{\text {prod }}} .
\end{array}\right.
$$

where $\rho_{\text {in }}(t)$ - a flow, included in a block of delay;

$\rho(t)$ - a flow, outcoming from a block of delay (production pace);

$\Lambda_{1}(t), \Lambda_{2}(t), \Lambda_{3}(t)$ - levels, that determine an amount of production, that is being in a process of production;

$\rho_{1}(t), \rho_{2}(t)$ - flows between levels;

$\xi^{\text {prod }}$ - an intercept of delay, that is determined by the duration of a production process.

One of the sought indicators is an optimal amount of materials order for production. [4]. In given paperwork an optimal size of the order is used as a criteria of total expenses on storing and duplication of an order, that is depended on the Wilson formula: 


$$
X=\sqrt{\frac{2 Y D}{I}},
$$

where $Y$-expenses on the delivery of a material unit;

$D-$ a necessity in a material;

$I$ - expenses on storing the unit of material.

In the process of production of SIP panels three types of materials are involved, and for each of them, there is a necessity to calculate value $X$. A necessity in the material is determined by an amount of material in a warehouse and an amount that is needed for fulfilling orders of wholesale customers. Expenses on delivery and storage of the unit of each kind are thought to be known.

This model has gained the program realization by means of electronic tables. Results of a computer experiment with the model are given in Figure 1.

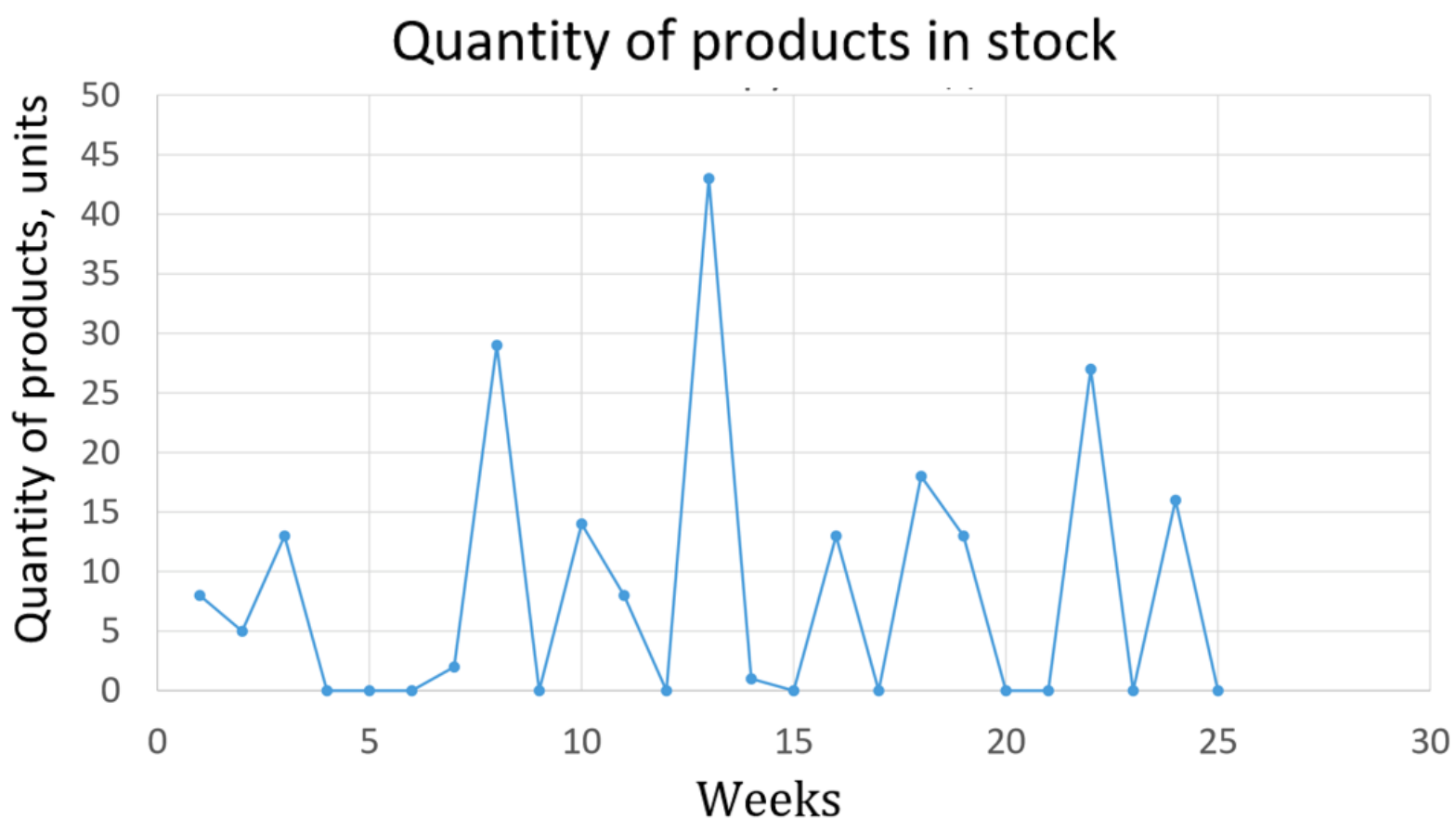

Figure 1. Results of calculating

Fluctuation in graph 1 is based on the irregularity of customers orders. Value of zero of a number of finished goods in a warehouse witness of the absence of output for fulfilling orders due to the availability of delays, between receiving of orders and fulfilling them.

The developed model and its implementation give a chance to analyze material flows in a manufacturing facility and enhance the effectiveness of managing it.

\section{References:}

1 Gorbunov A.R. (2008). Sistemnaya dinamika: modelirovanie prinyatiya strategicheskikh i operativnykh resheniy [System Dynamics: Modeling Strategic and Operational Decisions]. Biznes- 
informatika (electronic journal), vol. 04, no. 2, pp. 25-34. Retrieved from: http://ecsocman.hse.ru/ data/2011/11/28/1270196022/2008_2_(accessed 7 February 2019).

2 Stepanenko O.A. (2013). Modeljuvannja vypadkovykh ghroshevykh potokiv proektu metodom systemnoji dynamiky [Simulation of random cash flows by a method of system dynamics]. Naukovyj visnyk mizhnarodnogho ghumanitarnogho universytetu (electronic journal), no. 6, pp 140-144 Retrieved from: file://mac/Home/Downloads/Nvmgu_eim_2013_6_26\% 20(1).pdf (accessed 21 January 2019).

3 Solodovnik G.V. (2016). Instrumentaljni zasoby modeljuvannja socialjno-ekonomichnykh system [Instrumental modeling of socio-economic systems]. Kharkiv: Rozhko. (in Ukrainian)

4 Krjuchkova I.V. (2012). Optymizacija materialjnykh zapasiv na suchasnomu pidpryjemstvi: ekonomichnyj aspect [Optimization of inventories on modern enterprise: economic aspect]. Efektyvna ekonomika (electronic journal), no. 7, pp. 11-18. Retrieved from: http://www.economy.nayka.com.ua/ ?op=1\&z=1279 (accessed 5 February 2019). 